\title{
Deoxyribonucleic Acid Homology among Strains of the Lobster Pathogen 'Gaffkya homari' and Aerococcus viridans
}

\author{
By KATHERINE F. KELLY* AND J. B. EVANS \\ Department of Microbiology, North Carolina State University, \\ Raleigh, North Carolina 27607, U.S.A. \\ (Received 3 July 1973; revised I November 1973)
}

Gaffkya homari, a Gram-positive tetracoccus that causes a fatal septicaemia in lobsters, was first described by Hitchner \& Snieszko (I947). Subsequently Wood (I965) reported the isolation of both pathogenic and non-pathogenic strains of $G$. homari from lobsters; the pathogenicity of this species for lobsters has been confirmed (Rabin, 1965; Stewart, Foley \& Ackman, I969; Puzniak, Chesbro \& Evans, I97I; Tubiash \& Krantz, 1970).

There has been considerably less agreement concerning the phenotypic characteristics and taxonomic relationships of this organism. However, most such studies have been relatively cursory and largely limited to only one or two strains (Aaronson, 1956; Deibel \& Niven, I960; Evans \& Schultes, I969; Miller \& Evans, I970; Stewart et al. I969; Wood, 1965). The detailed procedures and results in most instances were not described. The most comprehensive study was that of Deibel \& Niven (1960), who included two strains of Gaffkya homari in their study of Gram-positive tetracocci. Even though these two cultures differed from each other in $\mathbf{2} 2$ of the 39 tests reported, it was concluded that they were indistinguishable from Aerococcus viridans and that the correct name for the species should be Pediococcus homari. Other authors have generally concurred in the inclusion of $G$. homari and $A$. viridans in a single species even though they disagree concerning the appropriate genus (Schultes \& Evans, I 971). The choice has been narrowed by the recent official rejection of the genus name Gaffkya (Editorial Secretary, I971). A close relationship to the genus Pediococcus is not supported by DNA homology studies (Schultes \& Evans, 197I), vitamin requirements (J. B. Evans, unpublished), or peptidoglycan composition (Nakel, Ghuysen \& Kandler, I97I). There seems to be no valid basis for considering this species to be any closer to the genus Pediococcus than it is to some other genera of Gram-positive cocci, and we believe it should be retained in the separate genus Aerococcus. The present study was designed to determine by means of DNA hybridization the homology among the lobster and non-marine strains of $A$. viridans.

\section{METHODS}

Cultures and growth conditions. The bacterial strains used in this study and their sources are included in Table I. Cultures for DNA extraction were grown in Trypticase Soy Broth (BBL, Division of Becton, Dickinson and Co.) at $30^{\circ} \mathrm{C}$ for $\mathrm{I} 7$ to $24 \mathrm{~h}$, depending on the growth rates of the different cultures. Labelled DNA was produced by incorporation in the growth medium of $0.33 \mu \mathrm{Ci} / \mathrm{ml}$ methyl- $\left[{ }^{3} \mathrm{H}\right]$ thymidine (New England Nuclear).

DNA base composition. For each culture unlabelled DNA was extracted and purified as described previously (Schultes \& Evans, 197I). The amount of DNA was determined by measuring extinction at $260 \mathrm{~nm}$ using a standard curve based on salmon sperm DNA.

* Present address: Department of Biology, College of Charleston, Charleston, South Carolina, U.S.A. 
The moles percentage of guanine plus cytosine was calculated from the thermal denaturation curve with the aid of a computer program developed as part of this study and based upon the method of Marmur \& Doty (I962).

DNA-DNA hybridization. Unlabelled DNA was denatured by heating for ro min at $100{ }^{\circ} \mathrm{C}$ in $\mathrm{SSC}(0.15 \mathrm{M}-\mathrm{NaCl}$ and $0.015 \mathrm{M}$-sodium citrate, $\mathrm{pH} 7.0)$ and $100 \mu \mathrm{g}$ of this DNA in $0.4 \mathrm{ml}$ of SSC was added to nitrocellulose membrane filters (type B-6, Schleicher and Schuell Co.) that had been soaked overnight in sixfold concentrated SSC at $4{ }^{\circ} \mathrm{C}$. The filters were washed with sixfold concentrated SSC, dried, cut in quarters, and vacuum-dried in scintillation vials. One $\mathrm{ml}$ of Denhardt's (1966) preincubation mixture with $30 \%$ dimethylsulphoxide (Rogul, Brendle, Haapala \& Alexander, 1970) was added to each vial and incubated at $60{ }^{\circ} \mathrm{C}$ for $4.5 \mathrm{~h}$. The filter quarters were blotted dry and returned to the vials from which the preincubation mixture had been poured. Labelled DNA from the reference strains was denatured and sheared as described previously (Schultes \& Evans, I97I), and $0.5 \mu \mathrm{g}$ samples in $0.5 \mathrm{ml}$ of twofold concentrated SSC added to appropriate filter quarters. These were incubated at $60{ }^{\circ} \mathrm{C}$ for $\mathrm{I} 6 \mathrm{~h}$, placed in an ice bath, washed with twofold concentrated $\mathrm{SSC}+30 \%(\mathrm{w} / \mathrm{v})$ dimethylsulphoxide, and washed with twofold concentrated SSC at $60^{\circ} \mathrm{C}$. After drying, the amount of labelled DNA bound on each filter was determined in a scintillation counter. Controls for non-specific binding and a homologous cross were included in each experiment. The percentage homology for heterologous crosses was calculated by considering the homologous cross equal to $100 \%$ homology.

\section{RESULTS AND DISCUSSION}

In DNA base composition the six Gaffka homari strains appear to have a slightly higher percentage GC than the three Aerococcus viridans strains (Table I). However, other studies in our laboratory have shown that other strains of $A$. viridans give values that completely overlap those for G. homari.

In DNA-DNA hybridization experiments two reference strains of Gaffkya homari and one of Aerococcus viridans were used as sources of the labelled, sheared DNA in the mobile phase (Table I). The very high degree of homology among the six strains from lobsters is shown with all three reference strains. With the two G. homari reference strains there was 93 to $97 \%$ homology with the other lobster strains and all six strains had 53 to $57 \%$ homology with the $A$. viridans reference strain.

The results also show a close relationship between the two groups of organisms. The strains of Aerococcus viridans had 76 to $86 \%$ homology with the two reference strains of Gaffkya homari - which was actually closer than their relationship to the reference strain of $A$. viridans ( 7 I to $73 \%$ ). However, this homology among the $A$. viridans strains was closer than that between the $A$. viridans reference strain and the six strains of $G$. homari ( 53 to $57 \%$ ).

The low homology values found for the three control organisms with all three reference strains serve to emphasize the relatively close relationship between the two groups of tetracocci. The Streptococcus faecalis strain had a DNA base composition that was within the range of values for the tetracocci and the Staphylococcus epidermidis strain had only a slightly lower percentage of guanine plus cytosine in its DNA. Yet under the conditions of the present study these other Gram-positive cocci, that also share numerous phenotypic similarities with the tetracocci, had homology values in the same range as did Escherichia coli and as reported previously for three strains of pediococci (Schultes \& Evans, I97I).

The high degree of homology among the lobster strains in contrast to the greater variation among the non-marine aerococci may well be a reflection of more constant environmental 
Table I. DNA homologies between strains of Gaffkya homari and Aerococcus viridans

\begin{tabular}{|c|c|c|c|c|}
\hline \multirow[b]{2}{*}{$\begin{array}{l}\text { Cultures used as source } \\
\text { of unlabelled DNA }\end{array}$} & \multirow[b]{2}{*}{$\begin{array}{l}\text { Percentage } \\
\mathrm{G}+\mathrm{C}\end{array}$} & \multicolumn{3}{|c|}{ Percentage bound DNA of reference strain } \\
\hline & & wC9 & 6870 & MK2OI \\
\hline G. homari $\mathrm{wC}^{*}$ & $38 \cdot 6$ & $94 \pm 4$ & $97 \pm 2$ & $57 \pm 5$ \\
\hline G. homari wC9* & $38 \cdot 4$ & $100 \pm 0$ & $97 \pm 6$ & $57 \pm 2$ \\
\hline G. homari wCIO* & $38 \cdot 8$ & $95 \pm 4$ & $97 \pm 7$ & $55 \pm 5$ \\
\hline G. homari $6870^{*}$ & $37 \cdot 5$ & $96 \pm 5$ & $100 \pm 0$ & $53 \pm I$ \\
\hline G. homari HTI† & $38 \cdot 2$ & $96 \pm I$ & $93 \pm 3$ & $56 \pm 2$ \\
\hline G. homari $10400 \ddagger$ & $37 \cdot 7$ & $95 \pm I$ & $95 \pm 6$ & $53 \pm 2$ \\
\hline A. viridans MК $20 \mathrm{I} \S$ & $37 \cdot 0$ & $80 \pm 6$ & $8 \mathbf{I} \pm 5$ & $100 \pm 0$ \\
\hline A. viridans $303 \|$ & $36 \cdot 4$ & $86 \pm I$ & $78 \pm \mathrm{I}$ & $73 \pm 3$ \\
\hline A. viridans LSI 7 II & $35 \cdot 5$ & $79 \pm 7$ & $76 \pm 8$ & $7 I \pm 3$ \\
\hline S. epidermidis $\mathrm{BP} 3 \mathrm{I} \|$ & $32 \cdot 5$ & $4 \pm 2$ & $8 \pm I$ & $7 \pm 2$ \\
\hline S. faecalis $\mathrm{H} 27 \mathrm{a}^{* *}$ & $36 \cdot 9$ & $2 \pm I$ & $5 \pm I$ & $6 \pm 3$ \\
\hline E. coli $\mathrm{KI} 2 \ddagger$ & $48 \cdot 9$ & $2 \pm I$ & $4 \pm I$ & $4 \pm 2$ \\
\hline
\end{tabular}

Relations among strains are expressed as percentages relative to the homologous reaction which is taken as $100 \%$. Three independent determinations were conducted with DNA from each reference strain and the range of reproducibility is shown.

* W. R. Chesbro, Department of Microbiology, University of New Hampshire, Durham, New Hampshire, U.S.A.

$\dagger$ H.S. Tubiash, Bureau of Commercial Fisheries, Oxford, Maryland, U.S.A.

\$ American Type Culture Collection, Rockville, Maryland, U.S.A.

$\$$ Isolated in this laboratory by M. A. Kerbaugh from a hospital environment.

II A. C. Baird-Parker, Unilever Research Laboratories, Sharnbrook, Bedford, Bedfordshire.

L. J. Serrano, Oak Ridge National Laboratories, Oak Ridge, Tennessee, U.S.A.

** J. O. Mundt, University of Tennessee, Knoxville, Tennessee, U.S.A.

parameters in the normal habitat of the lobster strains. Certainly there is strong evidence that both groups belong to the same species and, if one wishes to separate them, the lobster strains might be considered as a subspecies of the broader species (i.e.Aerococcus viridans subsp. homarus). Support for such a separation comes from the report of Puzniak et al. (I97I) that strains of $A$. viridans from hospital sources failed to exhibit pathogenicity when injected into lobsters, as well as from the DNA homology studies presented here.

This investigation was supported in part by Public Health Service Grant AI-07693 and Training Grant GM-OI265 from the National Institute of General Medical Sciences. We thank all those who contributed cultures, and Constance Puzniak and W. R. Chesbro for data on physiological and virulence tests.

\section{REFERENCES}

Aaronson, S. (1956). A biochemical-taxonomic study of a marine micrococcus, Gaffkya homari, and a terrestrial counterpart. Journal of General Microbiology 15, 478-484.

Deibel, R. H. \& Niven, C. F. (1960). Comparative study of Gaffkya homari, Aerococcus viridans, tetradforming cocci from meat curing brines, and the genus Pediococcus. Journal of Bacteriology 79, 175-180.

DenHARDT, D. (1966). A membrane-filter technique for the detection of complementary DNA. Biochemical and Biophysical Research Communications 23, 64I-646.

EdITORIAL SeCRETARY (197I). Rejection of the generic name Gaffkya Trevisan. International Journal of Systematic Bacteriology 21, I04-I05.

Evans, J. B. \& SChultes, L. M. (I969). DNA base composition and physiological characteristics of the genus Aerococcus. International Journal of Systematic Bacteriology 19, I59-163.

HitchNeR, E. R. \& SNIESZKo, S. F. (I947). A study of microorganism causing a bacterial disease of lobsters. Journal of Bacteriology 54, 48. 
Marmur, J. \& Doty, P. (1962). Determination of the base composition of deoxyribonucleic acid from its thermal denaturation temperature. Journal of Molecular Biology 4, 109-I I 8.

Miller, T. L. \& Evans, J. B. (1970). Nutritional requirements for growth of Aerococcus viridans. Jonrnal of General Microbiology 6r, I3I-I 35.

Nakel, M., Ghuysen, J. M. \& Kandler, O. (1971). Wall peptidoglycan in Aerococcus viridans strains 201 Evans and ATCCII563 and in Gaffkya homari strain ATCC10400. Biochemistry 10, 2170-21 75.

Puzniak, C. J., Chesbro, W. R. \& Evans, J. B. (I97I). Comparison of virulence of Gaffkya homari and Aerococcus viridans for Homarus americanus. In Bacteriological Proceedings, p. 47.

Rabin, H. (I965). Studies on Gaffkemia, a bacterial disease of the American lobster, Homaris americanus (Milne-Edwards). Journal of Invertebrate Pathology 7, 39I-397.

Rogul, M., Brendle, J. J., HaApala, D. K. \& Alexander, A. D. (1970). Nucleic acid similarities among Pseudomonas pseudomallei, Pseudomonas multivorans, and Actinobacillus mallei. Journal of Bacteriology Ior, $827-835$.

Schultes, L. M. \& Evans, J. B. (1971). Deoxyribonucleic acid homology of Aerococcus siridans. International Journal of Systematic Bacteriology 21, 207-209.

Stewart, J. E., Foley, D. M. \& ACkman, R. (i. (I969). Characteristics of Gaffkya homari, the causative agent of the lobster disease gaffkemia. Journal of the Fisheries Research Board of Canada 26, $1385-1389$.

Tubiash, H. S. \& Krantz, G. E. (1970). Experimental bacterial infection of the blue crab, Callinectes sapidus. In Bacteriological Proceedings, p. 27.

Wood, P. C. (1965). Gaffkaemia, the blood disease of lobsters. Journal of General Microbiology $\mathbf{4} \mathbf{r}$, xxviii. 